\title{
Hubungan Hasil Belajar Pjok dengan Hasil Belajar Matematika
}

\section{Gede Adi Mahardika1*}

1,2,3 Prodi Pendidikan Jasmani Olahraga Kesehatan dan Rekreasi, Universitas Pendidikan Ganesha, Singaraja, Indonesia

\section{ART ICLE INFO}

\section{Article history:}

Received February 04, 2020

Revised February 09, 2021

Accepted March 07, 2021

Available online July 25, 2021

Kata Kunci:

Hasil Belajar, PJOK, Matematika

Keywords:

Learning Outcomes, PJOK,

Mathematics

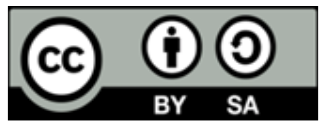

This is an open access article under the CC BY-SA license.

Copyright (ㄷ) 2021 by Author. Published by Universitas Pendidikan Ganesha.

\begin{abstract}
A B S T R A K
Masih kurangnya kemampuan siswa dalam berfikir logis, sikap jujur dan sportif, berpengaruh terhadap kemampuan bernalar siswa dalam pelajaran matematika. Penelitian ini bertujuan untuk menganalisis hubungan hasil belajar PJOK dengan hasil belajar Matematika peserta didik. Jenis penelitian ini adalah penelitian kuantitatif dengan pendekatan korelasional. Subjek penelitian adalah peserta didik dengan jumlah lima kelas dan jumlah sampel 148 orang peserta didik. Teknik pengambilan sampel adalah total sampling. Metode pengambilan data hasil belajar PJOK dan hasil belajar Matematika diambil dengan metode observasi, wawancara, dan pencatatan dokumen. Teknik analisis data yang dipergunakan adalah statistika korelasi yang terdiri dari analisis stastistik deskriptif, analisis stastistik inferensial. Uji hipotesis menggunakan analisis korelasi Product Moment. Hasil analisis menyajikan bahwa terdapat hubungan yang signifikan antara hasil belajar PJOK degan hasil belajar Matematika, yang ditunjukkan dengan hasil korelasi sebesar rhitung $(0.99)<$ rtabel (0.99). Dapat disimpulan bahwa terdapat hubungan yang signifikan antara hasil belajar PJOK dengan hasil belajar Matematika peserta didik. Implikasi penelitian ini memberikan dampak pada hasil belajar siswa yang semakin membaik.
\end{abstract}

\section{A B S T RA K}

The lack of students' ability to think logically, honest and sportsmanship, affects students' reasoning abilities in mathematics. This study aims to analyze the relationship between PJOK learning outcomes and participants' mathematics learning outcomes. This type of research is quantitative research with a correlational approach. The research subjects were students with a total of five classes and a sample of 148 students. The sampling technique is total sampling. The method of collecting data on PJOK learning outcomes and Mathematics learning outcomes was taken by the methods of observation, interviews, and document recording. The data analysis technique used is correlation statistics consisting of descriptive statistical analysis, inferential statistical analysis. Hypothesis testing using Product Moment correlation analysis. The results of the analysis show that there is a significant relationship between PJOK learning outcomes and Mathematics learning outcomes, which is indicated by the correlation results of rcount (0.99) <rtable (0.99). It can be concluded that there is a significant relationship between PJOK learning outcomes and students' mathematics learning outcomes. The implications of this research have an impact on student learning outcomes that are getting better.

\section{PENDAHULUAN}

Pendidikan merupakan suatu hal yang sangat penting dan tidak dapat dipisahkan dari kehidupan seseorang baik dalam keluarga, masyarakat dan bangsa (Pujianto, Sutisyana, Arwin, \& Nopiyanto, 2020). Pendidikan merupakan usaha sadar yang dilakukan seseorang untuk menjadi pribadi yang lebih baik dan mengembangkan potensi yang dimilikinya agar dapat bermanfaat bagi dirinya sendiri maupun orang lain dalam kehidupannya (Widiastrini, 2020) Tujuan pendidikan adalah untuk mempersiapkan generasi bangsa dengan wawasan pengetahuan yang tinggi dan membentuk watak yang bermanfaat dalam mencerdaskan kehidupan bangsa dan Negara (Ngubaidillah, 2018; Suryanti, Kristiantari, \& Suadnyana, 2016). Berdasarkan hal tersebut, sudah seharusnya kita bekerja keras dan meningkatkan kesadaran akan 
pentingnya pendidikan serta mulianya tujuan pendidikan itu sendiri. Berbagai upaya dilakukan untuk mengingkatkan kualitas pendidikan di Indonesia, salah satunya perubahan paradigma dalam pembelajaran yang dulunya teacher centre (berpusat pada guru) menjadi student centre (berpusat pada siswa) untuk memperoleh sesuatu sehingga belajar menjadi lebih bermakna.

Namun kenyataan dilapangan pendidikan saat ini masih menjadi masalah utama yang harus dipecahkan. Pendidikan yang diharapkan mampu untuk mengatasi berbagai masalahmasalah yang ada ternyata belum sepenuhnya berjalan sesuai harapan. Hal tersebut dikarenakan adanya masalah intern dalam bidang pendidikan. Banyak siswa yang mengalami kendala dalam meningkatkan hasil belajar. Kemampuan berpikir, bekerja ilmiah, dan kemampuan memecahkan masalah yang dihadapi dalam kehidupan nyata sehari-hari di kalangan para siswa tidak berkembang sesuai dengan harapan(Nadiya, Rosdianto, H., \& Murdani, 2016). Hal tersebut disebabkan karena guru dominan hanya menggunakan metode konvensional sehingga siswa tidak aktif dalam belajar. Aktivitas belajar merupakan rangkaian kegiatan secara sadar yang dilakukan seseorang sehingga mengakibatkan perubahan dalam dirinya yang berupa perubahan pengetahuan atau kemahiran yang sifatnya tergantung pada sedikit banyaknya perubahan (Ningsih, Miaz, \& Zikri, 2019; Sariayu \& Miaz, 2020). Kurangnya aktivitas belajar yang melibatkan siswa akan berdampak terhadap minat belajar siswa yang menurun sehingga hasil belajarnya tidak akan maksimal. Penelitian yang dilakukan oleh (Anika \& Fajar., 2020) juga menyatakan jika hanya ada beberapa siswa yang aktif maka proses pembelajaran tidak akan berjalan dengan optimal. Oleh karena itu dalam proses pembelajarn sangat diperlukan kerjasama antara guru dan siswa. Guru memberikan pembelajaran secara menarik dengan berbagai metode, sehingga siswa dapat terlibat dalam proses pembelajarannya. Seorang siswa yang berminat terhadap suatu mata pelajaran tertentu akan selalu berusaha untuk memberikan perhatian yang lebih besar dan dapat mempelajari mata pelajaran tersebut secara sungguh sungguh tanpa ada yang menyuruh dengan rasa senang (Setiawati, Parwata, \& Suratmin, 2020).

Pendidikan jasmani dan pendidikan matematika merupakan mata pelajaran yang wajib di ajarkan mulai dari sd hingga di perguruan tinggi. Pendidikan jasmani merupakan bagian yang tidak dapat dipisahkan dari kehidupan manusia, melalui pendidikan jasmani manusia dapat belajar lebih banyak hal yang berhubungan dengan afektif, kongnitif, dan psikomotor yang merupakan bekal manusia untuk mencapai tujuan hidup (Nugroho, 2015; Paramitha \& Tantra, 2018). Dalam proses pembelajaran, pendidikan jasmani tidak dapat dipisahkan dari unsur-unsur pelajaran sesuai dengan kaidah pendidikan jasmani yakni belajar sambil berolahraga (Daulay, Priono, \& Pasaribu, 2020). Pendidikan jasmani adalah bagian dari pendidikan keseluruhan yang mengutamakan aktivitas jasmani dan pembinaan hidup sehat untuk pertumbuhan dan perkembangan jasmani, mental, sosial, dan emosional yang serasi, selaras dan seimbang. aktivitas fisik yang teratur untuk menunjang tercapainya kebugaran jasmani yang baik pada anak, dengan tercapainya kebugaran jasmani yang baik harapannya dapat memberikan dampak positif dan dapat mendukung terhadap kegiatan lainnya dan dapat memberikan stimulus aktivitas gerak terhadap anak (Fatoni, Suroto, \& Indahwati, 2021). Melalui aktivitas fisik ini diharapkan tujuan pendidikan yang meliputi ranah kognitif, afektif, fisik, dan psikomotorik dapat terwujud (Suwandaru \& Hidayat, 2021).

PJOK juga merupakan pengembangan sikap positif dan ketrampilan gerak dasar serta berbagai aktivitas jasmani yang juga diikuti dengan kecerdasan intelektual, keterampilan berfikir kritis, berfikir cermat, dan berfikir logis dalam proses pembelajaran guna meningkatkan kesegaran jasmani peserta didik dan cara atau pola pikir yang jauh lebih maksimal untuk dapat melakukan berbagai kegiatan. Proses pembelajaran pendidikan jasmani di sekolah hendaknya benar-benar dapat dimanfaatkan oleh siswa dan dijadikan sebagai media untuk mendorong petumbuhan fisik, perkembangan psikis, ketrampilan motorik, pengetahuan dan penalaran, penghayatan nilai-nilai, serta pembiasaan pola hidup sehat yang bermuara untuk merangsang pertumbuhan dan perkembangan kualitas fisik dan psikis yang seimbang. Melalui Pendidikan Jasmani dan olahraga, diharapkan para siswa dapat lebih mudah menguasai konsepkonsep dan keterampilan yang lainnya, sehingga terjadi transfer hasil belajar pendidikan jasmani yang positif terhadap penguasaan konsep-konsep dan keterampilan bidang studi lainnya (Ritonga \& Yarni, 2019). Peningkatan kebugaran jasmani diharapkan dapat ditransfer secara positif ke dalam kemampuan belajar kognitif. Hal ini diharapkan tercermin dari meningkatnya hasil prestasi belajar siswa dalam proses pembelajaran matematika, ilmu pengetahuan alam (MIPA) dan ilmu pengetahuan sosial (IPS), yang perlu dibuktikan dalam penelitian ini (Sarumaha, Harefa, \& Zagoto, 2018; Zagoto, 2018). Salah satunya dalah dalam bidang studi matematika.

Mata pelajaran matematika dapat memperluas cakrawala berpikir peserta didik juga dapat mengembangkan kesadaran tentang nilai-nilai yang secara esensial terdapat didalamnya. Matematika merupakan pelajaran yang penting, terutama karena matematika dapat digunakan dalam kehidupan sehari-hari untuk menyelesaikan masalah (Limpo, Oetomo, \& Suprapto, 2013). Pelajaran matematika 
perlu diajarkan dari Sekolah Dasar sampai perguruan tinggi agar peserta didik mampu berpikir logis, analitis, sistematis, kritis dan kreatif serta memiliki kemampuan bekerja sama (Taslim, 2016). Peran guru pun sangat diperlukan dalam memfasilitasi pengalaman belajar yang menyenangkan dan mampu menstimulasi kemampuan berpikir kritis (Stephani, 2017). Pembelajaran matematika juga memiliki peranan yang sangat penting karena sebagai dasar logika atau penalaran dan penyelesaian kongnitif dari peserta didik yang digunakan dalam pelajaran lainnya.

Pembelajaran PJOK dan pembelajaran Matematika memiliki hubungan berdasarkan keterikatannya dari asfek kemampuan berfikir logis, berpikir kritis, berfikir cermat, sikap jujur dan sportif. Pada umumnya tujuan pembelajaran matematika adalah membentuk kemampuan bernalar peserta didik yang terukur dalam berfikir kritis, berfikir logis, kreatif, inovatif, pemecahan masalah, bersikap obyektif baik dibidang matematika itu sendiri ataupun dibidang pembelajaran PJOK (Widyastuti \& Pujiastuti, 2014). Keterkaitan PJOK dengan Matematika yaitu sebagai berikut, 1) Pembelajaran olahraga dapat dipadukan dengan pembelajaran matematika. 2) Pendidikan matematika dan olahraga saling menunjang dalam prestasi siswa dimana prestasi di bidang matematika cenderung meningkatkan kemampuan olahraga siswa, demikian pula sebaliknya. 3) Bidang olahraga memberikan banyak potensi materi pembelajaran matematika dimana beberapa cabang olahraga merupakan aktivitas yang populer di kalangan generasi muda 4) Analisis matematika dapat diaplikasikan untuk program-program di berbagai cabang olahraga. 5) Gerak fisik siswa yang teratur dapat meningkatkan prestasi pembelajaran matematika siswa (Listiwikono, 2018).

Berbicara mengenai pembelajaran tujuan dari sebuah pembelajaran adalah sebuah hasil belajar. Penelitian yang dilakukan oleh (Aisyah \& Dkk, 2017; Putra, 2017) yang menyatakan bahwa hasil belajar menjadi tolok ukur dalam sukses atau tidaknya kegiatan belajar mengajar (Aisyah \& Dkk., 2017; A. Putra, 2017). Untuk mencapai hasil belajar yang baik dalam pembelajaran PJOK, dan Matematika guru perlu meningkatkan kualitas belajar. Hasil belajar adalah suatu interaksi dimana dalam hasil belajar mengaitkan perbuatan, nilai, sikap dan keterampilan setelah melakukan suatu proses belajar, maka seseorang memperoleh suatu hasil belajar. Hasil belajar haruslah ada suatu perubahan dengan adanya interaksi antar guru dan peserta didik, kecerdasan intelektual merupakan kemampuan mental seseorang untuk yang sangat umum yang antara lain melibatkan kemampuan akal, merencana, memecahkan masalah, berfikir abstrak berfikir logis,berfikir kritis,berfikir cermat memahami ide ide yang kompleks. Secara umum hasil belajar Hasil belajar akan membantu mendorong keseluruhan daya penggerak didalam diri peserta didik yang menimbulkan kegiatan belajar, yang menjamin kelangsungan dari kegiatan pembelajaran dan yang memberikan arah pada kegiatan belajar, sehingga tujuan yang dikehendaki dapat tercapai didalam kegiatan belajar pembelajatan. "Hasil belajar adalah kemampuan-kemampuan yang dimiliki peserta didik setelah menerima pengalaman belajar. Hasil belajar dapat juga diartikan sebagai bentuk dari usaha yang telah dilakukan oleh peserta didik selama proses pembelajaran. hasil belajar yang telah diperoleh oleh peserta didik dijadikan sebagai bahan penyusun kemajuan dan perbaikan terhadap proses pembelajaran yang telah dilalui. Dari hasil belajar dapat diketahui sejauh mana peserta didik telah mampu memahami materi selama mengikuti pembelajaran serta hal yang perlu untuk diperbaiki selama pembelajaran (Pertiwi \& Renda, 2020). Untuk mendapatkan hasil belajar yang maksimal di dalam sebuah pembelajaran perlu yang namanya motivasi belajar yang di tekankan pada peserta didik yang dimana akan menambah minat peserta didik untuk belajar, dan trus menggali setiap informasi baru untuk meningkatkan hasil belajar. Meningkatkan motivasi dan aktivitas belajar siswa adalah keniscayaan dalam mewujudkan kegiatan pembelajaran berkualitas, karena peningkatan motivasi belajar berkontribusi langsung dan positif terhadap hasil belajar siswa (Mediawadi \& Trimawan, 2021).

Penelitian ini didukung dengan beberapa penelitian terdahulu yang dianggap relevan dengan variable penelitian ini, seperti 1) Penelitian yang dilakukan oleh (Lukmana \& Maksum, 2014) yang menunjukkan bahwa bahwa terdapat hubungan yang signifikan antara aktivitas olahraga dengan kemampuan memecahkan masalah pada siswa SMP Negeri 3 Nganjuk. 2) Penelitian oleh '(Ardian, Purwanto, \& Alfarisi, 2019) yang menunjukan bahwa adanya pengarauh dan hubungan positif yang signifikan antara kecerdasan emosional terhadap hasil belajar siswa kelas khusus olaharaga. Berdasarkan hasil penelitian yang relevan diatas dapat diketahui bahwa hubungan hasil belajar antara masing-masing mata pelajaran cukup bervariasi yakni ada yang memiliki keterkaitan dan ada yang tidak, sehingga menarik untuk diteliti. Adapun perbedaan penelitian ini dengan penelitian sebelumnya yakni pada penelitian ini peneliti mangamati hubungan anatara hasil belajar PJOK dengan pendidikan matematika. Dengan tujuan untuk menganalisis hubungan hasil belajar PJOK dengan hasil belajar Matematika peserta didik. 


\section{METODE}

Jenis penelitian ini dapat digolongkan ke dalam penelitian deskriptif korelasional yang bertujuan untuk mengetahui ada tidaknya hubungan hasil belajar PJOk dengn hasil belajar Matematika. Metode penelitian ini yaitu dengan metode expost facto, dengan pengambilan data yaitu total sampling (Sugiyono., 2016). Subjek atau Populasi adalah keseluruhan atau himpunan objek dengan ciri yang sama (Kanca, 2010). Subjek pada penelitian ini adalah peserta didik kelas VII SMP Negeri 3 Kubutambahan sebanyak lima kelas. Sedangkan sampel pada penelitian ini berjumlah 148 orang peserta didik. Data hasil belajar PJOK dan hasil belajar Matematika dikumpulkan dengan metode Observasi, Wawancara, pencatatan dokumen. Setelah data terkumpul data di analisis dengan teknik analisis stastistik deskriptif dan stastistik inferensial. Stastistik deskriptif yaitu digunakan untuk mempelajari tentang Cara penyusunan dan penyajian data yang dikumpulkan dalam suatu penelitian (Agung, 2016). Dengan menghitung, mean, modus, median, menghitung sandar deviasi (SD). Sedangkan stastistik inferensial adalah stastistik yang mempelajari tentang cara penarikan kesimpulan-kesimpulan mengenai keadaan populasi, berdasarkan hasil analisis data terhadap bagian dari populasi yang disebut sampel (Agung, 2016:3). Statistik inferensial terdiri dari Uji Normalitas Sebaran Data dan Uji hipotesis dilakukan untuk mengetahui hubungan antara variable hasil belajar PJOK dan hasil belajar Matematika.

\section{HASIL DAN PEMBAHASAN}

Data yang digunakan dalam hipotesis ini adalah data hasil yang dikumpulkan lewat obsevasi, wawancara dan pencatatan dokumen. Tujuan uji hipotesis ini untuk mengetahui dugaan sementara pada penelitian. Untuk mengetahui hipotesis peneliti ini maka harus melakukan uji normaltias dan uji homogenitas terlebih dahulu. Kedua pengujian tersebut untuk mengetahi apakah data berdistibusi normal atau tidak. Setelah itu data akan di uji dengan uji independent samples t-test. Hasil analisis statistika deskriptik dapat di lihat pada Tabel 1 beikut.

Tabel 1. Hasil analisis statistika deskriptif

\begin{tabular}{rccc}
\hline No & Analsis Deskripsi & PJOK & Matematika \\
\hline 1 & Mean & 84.5 & 84.6 \\
2 & Median & 78.9 & 80 \\
3 & Modus & 81.3 & 81 \\
4 & Standar Deviasi & 3.92 & 4 \\
\hline
\end{tabular}

Hasil analisis deskriptif data hasil belajar Matematika peserta didik yakni: mean $=72$, median $=68$, modus $=99$, standar deviasi 13 , dan rata-rata $=72.41$ sedangkan data hasil belajar PJOK peserta didik yakni: mean $=69$, median $=68$, modus $=72$, standar deviasi $=9$, dan rata-rata $=72.41$ perhitungan analisis data secara manual

\section{Uji Normalitas}

Pengujian ini bertujuan untuk mengetahui data berdistribusi normal atau tidak. Hasil uji normlitas dapat dilihat pada Tabel 2 berikut ini. Berdasarkna tabel uji normalitas, dinyatakan bahwa hasil belajar Matematika= 0.20 dan PJOK 0.66 diatas 0.05 dapat dinyatakan normal.

Tabel 2. Hasil Uji normalitas

\begin{tabular}{cccccc}
\hline No & Variabel & Normalitas & Syarat & Sig & Keterangan \\
\hline 1 & Hasil belajar Matematika & 0.86 & $>$ & 0.05 & Normal \\
2 & Hasil belajar PJOK & 0.63 & $>$ & 0.05 & Normal \\
\hline
\end{tabular}

\section{Uji Linearitas}

Uji Linearitas bertujuan untuk mengetahui apakah dua variable mempunyai hubungan yang linear atau tidak secara signifikan. Pengujian ini melihat bagaimana variable $(\mathrm{X})$ mempengaruhi variable (Y), baik itu pengaruh berbanding lurus maupun berbanding terbalik. Uji ini biasanya digunakan sebagai prasyarat dalam analisis korelasi atau regresi linear. Dua variable tersebut dikatakan linear apabila signifikansi lebih dari 0,05 sehingga pengambilan keputusan berupa terdapat hubungan yang linear. Hasi uji linearitas dapat di lihat pada Tabel 3 berikut. Berdasarkan tabel uji linearitas menunjukkan hasil nilai signifikansi linearity $0.49<0.05$ dan nilai signifikansi deviation from linearity $0.114>0.05$, maka hasil belajar PJOK dan Matematika peserta didik SMP N 3 Kubutambahan linear. 
Tabel 3. Uji linearitas

\begin{tabular}{lllllc}
\hline \multicolumn{1}{c}{ Variabel } & \multicolumn{1}{c}{ Nilai Sig } & & Syarat & Sig. & Keterangan \\
\hline Hasil belajar & Sig. Liearity & 0.00 & $<$ & 0.05 & Linear \\
PJOK dan & Sig. Deviation & 0.91 & & & \\
Matematika & From Liearity & & & & \\
\hline
\end{tabular}

\section{Uji Hipotesis}

Dalam pengujian hipotesis Jika nilai sig. (2-tailed) > 0,05 maka H0 diterima dan Ha ditolak, yang berarti tiak ada perbedaan rata-rata hasil belajar siswa pada kelas eksperimen dan kelas kontrol, namun Jika nilai sig. (2-tailed). < 0,05 maka H0 ditolak dan Ha diterima, yang berarti ada perbedaan rata-rata hasil belajar siswa Hasil uji hipotesis penelitian dapat dilihat pada tabel 4.

Tabel 4. Uji hipotesis

\begin{tabular}{lcccc}
\hline & Variable & rhitung & rtabel & Keterangan \\
\hline Hasil Belajar & 0.99 & 0.99 & Signifikan \\
PJOK dan & & & & \\
Hasil Belajar & & & \\
Matematika & & & \\
\hline
\end{tabular}

Berdasarkan tabel 4 menunjukkan nilai rhitung sebesar 0.99 dan rtabel 0.99 yang artinya rhitung < $r_{\text {tabel }}$ sehingga hasil pengujian hipotesis menunjukan terdapat hubungan antara hasil belajar PJOK terhadap hasil belajar Matematika peserta didik kelas VII SMP N 3 Kubutambahan. Dengan hasil korelasi ini dapat dinyatakan bahwa hasil belajar PJOK dan hasil belajar Matematika terdapat hubungan yang yang signifikan. Dan berdasarkan hasil analisis korelasi antara hasil belajar PJOK dan hasil belajar Matematika diperoleh nilai $r$ sebesar 0,99 dengan $p=0,000(p<0,05)$, menunjukkan terdapat hubungan yang positif signifikan.

\section{Pembahasan}

Berdasarkan pada penelitian ini hasil belajar PJOK dan hasil belajar Matematika memiliki hubungan positif signifikan dengan saling mempunyai kedekatan antara satu sama lain. Pembelajaran matematika merupakan salah satu mata pelajaran yang menuntut peserta didik untuk mampu berpikir secara logis, kritis, dan mampu memecahkan masalah yang ada dalam kehidupan sehari-hari, serta mampu mempertanggung jawabkannya (Cahyaningsih \& Ghufron, 2016; Steven, La Ndia, \& La Arapu, 2019). Hasil belajar matematika adalah hasil belajar yang dicapai seseorang setelah mengalami proses interaksi pelajaran mata pelajaran matematika (Punia, 2020). Penguasaan matematika sangat penting dalam menunjang keberhasilan pembangunan bidang pendidikan, karena bagi siswa penguasaan terhadap matematika akan menjadi sarana yang ampuh untuk mempelajari mata pelajaran lain. Salah satunya dalah mata pelajaran PJOK. Pendidikan jasmani adalah suatu usaha yang dilakukan agar dapat menciptakan lingkungan belajar yang bisa mempengaruhi potensi peserta didik agar berkembang dengan tingkah laku yang positif melalui aktivitas fisik. Aktivitas fisik ini berbentuk rangsangan yang dilakukan untuk mempengaruhi potensi-potensi atau minat bakat yang dimiliki peserta didik guna mencapai tujuan pendidikan yang meliputi ranah kognitif, afektif, fisik, dan psikomotorik dapat terwujud (Suwandaru \& Hidayat, 2021). Aktivitas Olahraga mengajarkan pada seseorang akan kedislipinan, jiwa sportivitas, tidak mudah menyerah, mempunyai jiwa kompetitif yang tinggi, semangat bekerja sama, mengerti adanya aturan dan berani mengambil keputusan (Lukmana \& Maksum, 2014). Hal ini sesuai dengan karakteristik peserta didik yang cenderung lebih senang bermain dan bergerak (Maryono, Budiono \& Okha, 2018). Dengan aktivitas fisik berupa olaharga akan berdampak terhadap kebugaran jasmani dan rohani siswa sehingga siswa senang dan semangat mengikuti proses pembelajaran, hal ini akan berdampak terhadap hasil belajar siswa. Salah satunya adalah hasil belajar matematika. Dengan hal tersebut kita dapat melihat hubungan hasil belajar PJOK dengan hasil belajar matematika. Manfaat PJOK dengan matematika yaitu pembelajaran matematika (Geometri) dengan memanfaatkan media PJOK sangat menarik dan mampu menumbuh kembangkan minat belajar peserta didik sehingga mereka memiliki karakter, ilmu pengetahuan dan ketrampilan gerak yang baik.

Hasil penelitian ini sejalan dengan penelitian yang dilakukan oleh 1) (Listiwikono, 2018) yang menunjukkan bahwa pendidikan matematika dan olahraga saling menunjang dalam prestasi siswa dimana prestasi di bidang matematika cenderung meningkatkan kemampuan olahraga siswa, demikian pula sebaliknya. 2) penelitian oleh (E. P. Putra, 2019) yang menunjukkan ada hubungan antara kebugaran 
jasmani dengan tingkat konsentrasi peserta didik di SMP Negeri 1 Gondang. 3) penelitian oleh (Jani, Alghadari, \& Chairunnisa, 2020) yang menunjukkan terdapat hubungan yang signifikan antara kebiasaan berpikir dengan hasil belajar matematika siswa. Mengingat bentuk Lapangangan PJOK itu bersifat riil, maka perlu memanfaatkan media matematika sebagai bentuk Inovasi dan Kreatifitas Guru di dalam melakukan Pembelajaran Geometri dan Pengukuran. hal ini mejadikan pembelajaran PJOK dan matematika memiliki hubungan atau keterikatan satu sama lain. Untuk dapat meningkatkan hasil belajar peserta didik guru harus mampu meningkatkan kualitas pembelajarannya dengan menggunakan metode serta model pembelajaran yang tepat, yang mampu memberikan dorongan serta motivasi kepada peserta didik agar belajar dengan maksimal dan meningkatkan kualitas diri.

\section{SIMPULAN DAN SARAN}

Berdasarkan hasil analisis data dan pembahasan hasil penelitian, dapat disimpulakan bahwa terdapatnya hubungan yang signifikan antara hasil belajar PJOK dengan hasil belajar Matematika peserta didik menunjukkan bahwa dengan olahraga yang cukup fisik yang sehat, dan bugar, peserta didik mampu mengikuti proses pembelajaran guna membangun kemampuan berfikir logis, kritis serta kemampuan pemecahan masalah secara maksimal sehingga berdampak terhadap motivasi dan hasil belajar siswa. Sejalan dengan hasil penelitian tersebut, disarankan agar guru-guru dapat meningkatkan hasil belajar baik matematika maupun pjok dengan meningkatkan motivasi siswa untuk lebih giat dalam melaksanakan olahraga ataupun aktivitas fisik guna meningkatkan kemampuan afektif, kognitif dan psikomotorik siswa. Selain itu, guru hendaknya terus melakukan inovasi model pembelajaran sehingga dapat meningkatkan kualitas proses dan hasil belajar.

\section{DAFTAR RUJUKAN}

Agung, A. A. G. (2016). Statistika Dasar Untuk Pendidikan. Yogyakarta: Deepublish.

Aisyah, \& Dkk. (2017). Analisis Faktor Penyebab Rendahnya Hasil Belajar Peserta Didik pada Mata Pelajaran Ekonomi Di SMA Negeri 15 Palembang. Jurnal Profit (Online), 4. https://doi.org/10.36706/jp.v4i1.5572.

Anika, \& Fajar. (2020). Efektivitas Model Pembelajaran Kooperatif Tipe Make-A Match Dalam Meningkatkan Kompetensi Sikap Siswa dan Kompetensi Pengetahuan Siswa Pada Pelajaran IPS. Jurnal Ilmiah Sekolah Dasar, 4(1), 80-85. https://doi.org/10.23887/jisd.v4i1.24047.

Ardian, A., Purwanto, S., \& Alfarisi, D. S. (2019). Hubungan prestasi belajar siswa kelas khusus olahraga dengan kecerdasan emosional. Jurnal Keolahragaan, 7(2), 126-134. https://doi.org/10.21831/jk.v7i2.28103.

Cahyaningsih, U., \& Ghufron, A. (2016). Pengaruh Penggunaan Model Problem-Based Learning Terhadap Karakter Kreatif Dan Berpikir Kritis Dalam Pembelajaran Matematika. ,. Jurnal Pendidikan Karakter, 6(1), 104-115. https: //doi.org/10.21831/jpk.v0i1.10736.

Daulay, D. E., Priono, J., \& Pasaribu, A. M. N. (2020). Efektifitas Pembelajaran dengan Media untuk Perbaikan Hasil Lompat Jauh. COMPETITOR: Jurnal Pendidikan Kepelatihan Olahraga, 12(2), 7482. https://doi.org/10.26858/cjpko.v12i2.13988.

Fatoni, R. A., Suroto, \& Indahwati, N. (2021). Pengaruh aktivitas fisik program gross motor skill terhadap indeks massa tubuh dan tingkat kebugaran jasmani. MULTILATERAL: Jurnal Pendidikan Jasmani Dan Olahraga, 20(1), 1-10. https://doi.org/10.20527/multilateral.v20i1.9539.

Jani, F., Alghadari, F., \& Chairunnisa. (2020). Hubungan antara Kebiasaan Berpikir dan Hasil Belajar Matematika Siswa SMP. Prosiding Seminar Nasional Pendidikan STKIP Kusuma Negara II, 363-368. Retrieved https://jurnal.stkipkusumanegara.ac.id/index.php/semnara2020/article/view/780/429.

Kanca, I. N. (2010). Metode Penelitian Pengajaran Pendidikan Jasmani dan Olahraga. Singaraja: urusan Pendidikan Jasmani, Kesehatan, dan Rekreasi. Fakultas Olahraga dan Kesehatan Universitas Pendidikan Ganesha Singaraja.Undiksha.

Limpo, J. N., Oetomo, H., \& Suprapto, M. H. (2013). Pengaruh Lingkungan Kelas terhadap Sikap Siswa untuk Pelajaran Matematika. HUMANITAS (Jurnal Psikologi Indonesia), 10(1), 37-48.

Listiwikono, E. (2018). Analisis Peran Timbal Balik Pendidikan Matematika dan Olahraga. Prosiding Seminar Nasional IPTEK Olahraga (SENALOG), 1(1), 35-39. Retrieved from. https://ejournal.unibabwi.ac.id/index.php/semnassenalog/article/view/186.

Lukmana, R. C. H., \& Maksum, A. (2014). Hubungan Antara Aktivitas Olahraga Dengan Kemampuan Memecahkan Masalah. Jurnal Pendidikan Olahraga Dan Kesehatan, 2(1), 45-48.

Maryono, Budiono, H., \& Okha, R. (2018). Implementasi Pendidikan Karakter Mandiri Di Sekolah Dasar. 
Jurnal Gentala Pendidikan Dasar, 3(1), 20-38. https://doi.org/10.22437/gentala.v3i1.6750.

Mediawadi, N. K. D., \& Trimawan, I. K. (2021). Peningkatan Hasil Belajar IPA dengan Model Quantum Teaching. Journal for Lesson and Learning Studies, 4(1), 88-95. https://doi.org/10.23887/jlls.v4i1.35262.

Nadiya, N., Rosdianto, H., \, \& Murdani, E. (2016). Penerapan Model Pembelajaran Group Investigation (gi) untuk Meningkatkan Keterampilan Berpikir Kritis Siswa pada Materi Gerak Lurus Kelas X. JIPF (Jurnal Ilmu Pendidikan Fisika), 1(2), 49. https://doi.org/10.26737/jipf.v1i2.63.

Ngubaidillah, A. (2018). Pengaruh Media Visual Menggunakan Aplikasi Lectora Inspire Terhadap Hasil Belajar Peserta Didik. Jurnal Penelitian Pendidikan, 35(2).

Ningsih, S. R., Miaz, Y., \& Zikri, A. (2019). Model Discovery Learning Untuk Meningkatkan Aktivitas Dan Hasil Belajar Tematik Terpadu Di Sekolah Dasar. Jurnal Basicedu, 3(4), 1065-1072. https://doi.org/10.31004/basicedu.v3i4.203.

Nugroho, A. T. (2015). Meningkatkan Hasil Belajar Bola Voli Melalui Modifikasi Peraturan Permainan Dan Menggunakan Media Video Di Smk Negeri 1 Sedan Tahun Ajaran 2013/2014. Journal of Physical Education, Sport, Health and Recreations, 4(15), 2239-2245. https://doi.org/10.15294/active.v4i12.8796.

Paramitha, \& Tantra, S. (2018). Revitalisasi Pendidikan Jasmani untuk Anak Usia Dini melalui Penerapan Model Bermain Edukatif Berbasis Alam. Jurnal Pendidikan Jasmani Dan Olahraga, 3(1), 41-51. https://doi.org/10.17509/jpjo.v3i1.10612.

Pertiwi, P. A. I., \& Renda, N. T. (2020). Penerapan Model Pembelajaran Kooperatif Tipe Student Team Achievement Division (Stad) Berbantuan Media Konkret Untuk Meningkatkan Hasil Belajar Matematika. Jurnal Ilmiah Pendidikan Profesi Guru, 2(3), 216-227. https: //doi.org/10.23887/jippg.v2i3.14275.

Pujianto, D., Sutisyana, A., Arwin, A., \& Nopiyanto, Y. E. (2020). . (2020). Pengembangan Model Latihan Passing Sepakbola Berbasis Sasaran Teman.,. Journal Coaching Education Sports, 1(1), 1-12. https://doi.org/10.31599/jces.v1i1.81.

Punia, I. W. (2020). Peningkatan Hasil Belajar Matematika Melalui Penerapan Model Pembelajaran Kooperatif Tipe Think Pair Share. Jurnal Pendidikan Matematika Undiksha, 11(1), 21-30. https://doi.org/10.23887/jjpm.v11i1.24312.

Putra, A. (2017). Pendekatan Pembelajaran Aktif, Kreatif, Efektif Dan Menyenangkan Ditinjau dari Hasil Belajar,. Jurnal Pendidikan Matematika, 5(2), 129-140. https://doi.org/10.30738/.v5i2.1073.

Putra, E. P. (2019). Hubungan Kebugaran Jasmani Terhadap Tingkat Konsentrasi Peserta Didik (Studi Pada Peserta Didik Smp Negeri 1 Gondang Mojokerto). JPOK: Jurnal Pendidikan Jasmani, 7(3). Retrieved from https://ejournal.unesa.ac.id/index.php/jurnal-pendidikanjasmani/article/view/31375.

Ritonga, I., \& Yarni, N. (2019). Hubungan Kesegaran Jasmani Dan Motivasi Belajar Dengan Hasil Belajar Siswa Kelas V Sdn 12 Pulau Punjung. Jurnal Review Pendidikan Dan Pengajaran, 2(2), 276-284. Retrieved from https://journal.universitaspahlawan.ac.id/index.php/jrpp/article/view/484/730.

Sariayu, M. R., \& Miaz, Y. (2020). Peningkatan Aktivitas Belajar Siswa Melalui Model Think Pair Share di Sekolah Dasar. Jurnal Basicedu, 4(2), 295-305. https://doi.org/10.31004/basicedu.v4i2.337.

Sarumaha, R., Harefa, D., \& Zagoto, M. M. (2018). Upaya Meningkatkan Kemampuan Pemahaman Konsep Geometri Transformasi Refleksi Siswa Kelas XII-IPA-B SMA Kampus Telukdalam Melalui Model Pembelajaran Discovery Learning Berbantuan Media Kertas Milimeter. Jurnal Education and Development, 6(1), 90-96. https://doi.org/10.37081/ed.v6i1.668.

Setiawati, K. S., Parwata, I. G. L. A., \& Suratmin. (2020). Pengaruh Model Pembelajaran Dan Minat Belajar Terhadap Hasil Belajar Senam Lantai. JURNAL PENJAKORA, 7(1), 17-29. https://doi.org/10.23887/penjakora.v7i1.24444.

Stephani, M. R. (2017). Stimulasi Kemampuan Berpikir Kritis Melalui Pembelajaran Berbasis Masalah Pada Pendidikan Jasmani. Jurnal Pendidikan Jasmani Dan Olahraga, 2(1), 16-27. https: //doi.org/10.17509/jpjo.v2i1.6397.

Steven, D., La Ndia, L. N., \& La Arapu, L. A. (2019). Pengaruh Model Problem Based Learning Terhadap Kemampuan Berpikir Kritis Matematis Peserta Didik Kelas VIII SMP Negeri 2 Kendari. Jurnal Penelitian Pendidikan Matematika, 7(3), 15. https://doi.org/10.36709/jppm.v7i3.9278.

Sugiyono. (2016). Metode Penelitian Kuantitatif, Kualitatif, dan R \& D. Bandung: Alfabeta.

Suryanti, N. P. E., Kristiantari, M. G. R., \& Suadnyana, I. N. (2016). Upaya Meningkatkan Perkembangan Sosial Emosional Melalui Kegiatan Permainan Tradisional Ular Naga Pada Anak Kelompok B. EJournal Pendidikan Anak Usia Dini UNiversitas Pendidikan Ganesha, 4(1).

Suwandaru, C., \& Hidayat, T. (2021). Hubungan Aktivitas Fisik Dengan Prestasi Belajar Siswa Smk Negeri 1 Surabaya. Jurnal Pendidikan Olahraga Dan Kesehatan, 9(1), 113-119. Retrieved from. 
https://ejournal.unesa.ac.id/index.php/jurnal-pendidikan-jasmani.

Taslim. (2016). Upaya Peningkatan Aktivitas dan Hasil Belajar Matematika melaluiPendekatan Matematika Realistik Di Kelas V III.3 SMP. Jurnal Konseling Dan Pendidikan, 4(3), 62-74. https://doi.org/10.29210/114500.

Widiastrini, N. N. P. (2020). Upaya Meningkatan Hasil Belajar Matematika Siswa Kelas X AK 3 SMK N 1 Mas Ubud dengan Menerapkan Model Discovery Learning Berbantuan LKS Terstruktur. Journal of Education Action Research, 4(4), 415-421. https://doi.org/10.23887/jear.v4i4.28507.

Widyastuti, N. S., \& Pujiastuti, P. (2014). Pengaruh Pendidikan Matematika Realistik Indonesia (Pmri) Terhadap Pemahaman Konsep Dan Berpikir Logis Siswa. Jurnal Prima Edukasia, 2(2), 183-192. https://doi.org/10.21831/jpe.v2i2.2718.

Zagoto, M. M. (2018). Pengembangan Perangkat Pembelajaran Matematika Berbasis Realistic Mathematic Educations Untuk Siswa Kelas V Sekolah Dasar,. Jurnal Education And Development, 3(1), 53. https://doi.org/10.37081/ed.v3i1.139. 